\title{
Article
}

\section{The Challenge of Educating Purposeful Teachers in Finland}

\author{
Elina Kuusisto ${ }^{1, *(\mathbb{D})}$ and Kirsi Tirri ${ }^{2}(\mathbb{D}$ \\ 1 Faculty of Education and Culture, Tampere University, 33100 Tampere, Finland \\ 2 Faculty of Educational Sciences, University of Helsinki, 00170 Helsinki, Finland \\ * Correspondence: elina.kuusisto@tuni.fi
}

\section{check for}

updates

Citation: Kuusisto, E.; Tirri, K. The Challenge of Educating Purposeful Teachers in Finland. Educ. Sci. 2021, 11, 29. https://doi.org/10.3390/ educsci11010029

Received: 18 December 2020 Accepted: 11 January 2021 Published: 14 January 2021

Publisher's Note: MDPI stays neutral with regard to jurisdictional clai$\mathrm{ms}$ in published maps and institutional affiliations.

Copyright: $\odot 2021$ by the authors. Licensee MDPI, Basel, Switzerland. This article is an open access article distributed under the terms and conditions of the Creative Commons Attribution (CC BY) license (https:// creativecommons.org/licenses/by/ $4.0 /)$.

\begin{abstract}
This article discusses the challenges of educating teachers in Finland. As a goal in teacher education for the 21st century we propose the purposeful teacher, referring to a teacher who has a long-term moral commitment to serve students, the school community and society. Our data collected from student $(N=912)$ and practising $(N=77)$ teachers yielded information on the purposes they identified as important in their lives. The survey included quantitative instruments and openended questions. The teachers identified happiness, relationships, work and self-actualisation as the most important contents of their aspirations. All the content categories could be understood as potential purposes in that the benefit extended beyond the teachers themselves. However, almost half of the student teachers $(46 \%)$ and over half of teachers $(55 \%)$ revealed only self-orientation. Less than half of them $(43 \%, 36 \%$, respectively) showed a beyond-the-self orientation, which is indicative of a purposeful teacher. Among the practising teachers, teaching appeared to be mainly a mediating factor in realising their purposes or aspirations. These results have implications related to contemporary teacher education in Finland. Both pre- and in-service teachers need to know about purposeful teaching in order to find meaning in their work.
\end{abstract}

Keywords: purpose in life; purposeful teacher; teacher education; Finland

\section{Introduction}

The changing situation in teacher education and the new demands of the 21st century call for teachers who find both a personal and a societal purpose in teaching, and who can commit to the teaching profession in the long term [1]. We propose purposeful teaching as a goal in teacher education to meet the challenges of the 21 st century. Finland needs teachers who are ethical professionals with the freedom and responsibility to teach in ways that build meaning and purpose for themselves and for their students. Our aim in this article is to find out what purposes Finnish preservice and in-service teachers identify as important in their lives and in their profession.

A major goal within research-based teacher education in Finland for the last thirty years has been to produce pedagogically thinking, academic and autonomous teachers [2]. The new demands of the twenty-first century and the decreasing number of aspiring teachers emphasise the need for meaningful teacher education that combines the personal and professional interests of the learners [3].

As a notion, the purposeful teacher for the twenty-first century builds on the concept of purpose in education. In their relatively novel operationalisation, Damon, Menon, and Bronk [4] define purpose as "a stable intention to accomplish something that is both meaningful to the self and of consequence beyond the self over time" (p. 212). This definition is rooted in Viktor Frankl's [5] notion concerning the role of meaning and purpose in individual well-being, resilience and agency: one can find meaning through purpose in situations in which even basic needs are not met. In other words, knowing one's goals and committing oneself to them constitutes a moral beacon or compass [6] that encourages one to overcome challenges and stress and to find hope and resilience for the future. Using Damon et al.'s [3] definition of purpose as a basis, Tirri [1] describes a 
purposeful teacher as someone with a long-term moral commitment to teaching that is both meaningful personally, and benefits students, colleagues and society. These definitions of purpose and a purposeful teacher share three dimensions: (1) long-term engagement, (2) personal meaningfulness, and (3) contribution beyond-the-self. The beyond-the-self dimension highlights the noble and moral character of purpose [7]. Accordingly, neither an aspiration nor a teacher devoid of prosocial aims can be identified as purposeful.

According to Day [8], highly committed teachers are associated with quality, vocation, calling and moral purpose. He also argues that moral purpose defines the nature of professionalism in teaching, the implication being that teaching is not just a job [8]. It could therefore be considered a vocation requiring deep personal commitment, as well as a profession with clear ethical codes [9]. As Tirri [1] states: "purposeful teachers are those who can combine the vocational and professional aspects in their work" (p. 2). In other words, teachers need to internalise a purpose as a virtue if they are to serve others within their profession [10]. Virtue-based approaches to education may help teachers to experience teaching as a morally fulfilling experience and allow them to reflect their personal purposes in relation to work [11]. Moral purposes in this context include the projection of optimism for the present and the future, commitment, and resilience to teaching in demanding circumstances [1].

Earlier research conducted among Finnish teachers has shown that they cannot separate personal and professional aspects in their teaching [9]. Their own moral character influences how they interact with their pupils and find meaning in their work. Ethical codes for teachers provide a professional value basis and guidance on how to develop in their profession. The ethical code for teaching in Finland, established in 1998, defines dignity, truthfulness, fairness, responsibility and freedom as core values [12]. It also highlights commitment to students, colleagues and the school community, as well as the importance of maintaining one's own well-being. These commitments were further strengthened through the Comenius Oath for teachers introduced in 2017 [13]:

"As a teacher I am engaged in educating the next generation, which is one of the most important human tasks. My aim in this will be to renew and pass on the existing reserve of human knowledge, culture and skills. I will make continuous efforts to maintain and develop my professional skills, committing myself to the common goals of my profession and to the support of my colleagues in their work. I will act in the best interests of the community at large and strive to strengthen the esteem in which the teaching profession is held".

New teachers taking this Oath demonstrate their commitment to the ethical values and practices of their profession, in a similar manner to medical doctors abiding by the code of medical ethics.

The Finnish teachers' ethical code and Comenius Oath reflect Oser's [14] professional ethos of teachers that requires devotion to responsibility for actualizing justice, care, and truthfulness in instruction and interaction. Differences in ethos relate to how these dimensions are combined in teachers' daily practices, and the kind of strategies that are adopted if these values cannot be realised simultaneously: this is a moral dilemma in teaching [14]. In the Finnish context, teaching is understood as a moral activity, and teachers see themselves as ethical professionals who are committed to acting in the best interests of their students [15]. However, this kind of ethos cannot be taken for granted. In terms of teacher education, therefore, there is a constant need to update curricula to meet challenges related to changing society and globalisation.

In our vision to educate purposeful teachers we join researchers e.g., [16,17] and institutes of higher education [18] with a growing interest in the well-being of students, manifested in their support of reflection on who they want to become as persons and what they think would be a meaningful professional life. In recent years, for example, top US universities such as Harvard, New York University, Stanford, and Yale have created courses and programmes that give students the opportunity to reflect on their values, goals, and commitments, thereby to cultivate and develop their beyond-the-self oriented purposes 
(e.g., [18]; see also [6,19]). The present study explores the extent to which the goal of the purposeful teacher presented above is evident in empirical data gathered from Finnish student teachers and practising teachers. We sought answers to the following research questions:

1. What purposes do Finnish teachers find important in their lives?

2. How do Finnish teachers incorporate professional aspects into their life purposes?

\section{Materials and Methods}

\subsection{Participants}

This study consists of two sub-studies. The participants of the first one were Finnish student teachers from the University of Helsinki $(N=912$, age $M=27.79, S D=7.53$, $\min 18$, $\left.\max 57 ; n_{\text {female }}=728 ; 80 \%, n_{\text {male }}=177 ; 19 \%, n_{\text {no gender information }}=7 ; 1 \%\right)$, who completed the survey at the beginning of "General didactics" course $(n=602 ; 66 \%)$ or at the beginning of their teaching practicum course $(n=310 ; 34 \%)$. The aims of the participants were to become: (1) Kindergarten teachers specialised in early-childhood education and care ( $n=172 ; 19 \%)$; (2) class teachers at elementary school (grades $1-6 ; n=141 ; 18 \%$ ); and (3) subject teachers at lower- and upper-secondary schools (grades 7-9, I-III, $n=576 ; 63 \%$ ). The Kindergarten and class teachers were majoring in educational sciences. The subject teachers were majoring in foreign languages $(n=115)$; maths and science $(n=100)$; Finnish language and literature $(n=96)$; religious education $(n=67)$; handicrafts and home economics $(n=56)$; adult education $(n=50)$; social sciences $(n=49)$; biology and geography $(n=38)$; and special education $(n=21)$; no answer $(n=6)$.

The participants of the second sub-study were practising teachers in a Finnish school for basic education $\left(N=77\right.$, age $M=42, S D=11.13$, $\min 24$, $\max 68, n_{\text {female }}=63 ; 82 \%$, $n_{\text {male }}=14 ; 18 \%$ ) in Helsinki. They included class teachers (grades $1-6 ; n=27 ; 35 \%$ ) and subject teachers (grades $7-9 ; n=35 ; 47 \%$ ). Thirteen (18\%) of them taught special-education classes or provided such services. One did not specify the field. The class teachers had majored in educational sciences. The subject teachers had majored in foreign languages $(n=9)$; maths and science $(n=7)$; Finnish language and literature $(n=6)$; handicrafts and home economics $(n=5)$; social sciences $(n=2)$; biology and geography $(n=2)$; physical education $(n=2)$; music education $(n=2)$.

\subsection{Procedure and Instruments}

In the first sub-study the student teachers answered an online version of the Youth Purpose Around the World survey [20], of which two measures were used in the present study. The authors of this paper, who are native speakers of Finnish, translated the measures from English into Finnish, and the questions were back-translated into English to confirm the accurate conveyance of the meaning.

Contents of purpose among the student teachers were assessed on a 20-item version of Roberts and Robins's [21,22] Life Goals Questionnaire, which has seven content areas: relationship-related ( $\alpha=0.609,3$ items), hedonistic ( $\alpha=0.721,3$ items), social $(\alpha=0.625$, 2 items), economic ( $\alpha=0.721,4$ items), religious ( $\alpha=0.870,2$ items), political ( $\alpha=0.589$, 2 items), and aesthetic ( $\alpha=0.696,4$ items). The items were rated on a five-point Likert scale in response to the question: "How important are the following goals in your life?" ( 1 = not important to me, $5=$ very important to me). For example, the relationship goal was measured as follows: "having good relationships with my family members", "having children", and "having a satisfying marriage/relationship." The hedonistic goal items were: "having new and different experiences", "having an exciting lifestyle", and "having fun", and the social goals: "volunteering in the community" and "helping others in need". The fact that the political dimension contained only two items could explain the below 0.60 alpha value that indicates low internal consistency.

The respondents were also asked an open-ended question: "What is your purpose in life?" [23], the aim being to see how well Roberts and Robins's [21] questionnaire captures 
future teachers' aspirations and to find out how these student teachers incorporated professional aspects into their life purposes.

In the second sub-study, practising teachers answered the same open-ended question as the student teachers, as well as an explicit question designed for the study about how their purpose related to their profession: "How is teaching related to your purpose in life"?

\subsection{Analyses}

The scales of Roberts and Robins's [21] Life Goals Questionnaire were tallied, and the means, standard deviations and correlations were calculated. Spearman's nonparametric correlations were also computed in relation to the background variables (gender, age and education). IBM SPSS Statistics was utilised in these analyses. Further, following the analysis of the qualitative data, the results were quantified, cross-tabulated and subjected to Pearson's chi-square test, with the same background variables as mentioned above. The simultaneous assessment of the quantitative and qualitative results facilitated triangulation of the datasets, which were mixed and brought together to complement each other and thereby build a more valid and holistic picture of the topic in question [24].

A qualitative content analysis [25] of the written descriptions was conducted on two levels. The unit of analysis on the first level comprised words, phrases or sentences that communicated one specific content category. Roberts and Robins's [21] seven categories mentioned above were utilised as a deductive framework, and there were four additional categories (happiness, self-actualisation, work, and health) identified in previous studies on Finnish students of social services [26] and theology [27]. A total of 2095 content categories were identified from the descriptions given by the student teachers $(N=912)$, indicating 2.3 per respondent; the corresponding figures among the practising teachers $(N=77)$ were 122 in total and 1.6 per respondent. Below we present typical responses with symbols referring to the units of analysis:

“Happiness" (Student teacher 1007).

"Family, good standard of living, nice job, feeling good and happiness" (Student teacher 4764).

"To be present for myself and other people and make the world a better place for every one of us. Distribute humanity, understanding and friendship, experience and make memories." (Student teacher 1001).

(Symbol $=$ Content category: Bolding $=$ Happiness, Italics $=$ Relationships, Underlining = Work, Bolding and Italics $=$ Social, Bolding and underlining $=$ Economics, Italics and underlining: hedonism).

These examples show the relatively condensed nature of the participants' responses, which was also the case with the practising teachers' statements. Therefore, all individual words were considered in the analysis.

Second, we analysed the self- and beyond-the-self (BTS) -orientations in the content categories. For example, the sentence, "to live a happy life and to make others happy, too" implies an association between happiness and both self- and BTS-orientation. Thus, the second unit of analysis was the beneficiary of the aspiration, whether it was the teachers themselves or/and others. The coding was entered into an Excel table in which each content category covered two columns, one for self- and one for BTS-orientation. If the teacher did not explicitly mention any beneficiaries, self-focus was assumed.

The practising teachers' answers to the question "How is teaching related to your purpose in life?" comprised descriptions defining associations between teaching and purpose. They were coded into three categories: self, other, and self-and-other, utilising the same protocol as described above.

To check reliability, both authors coded 10 per cent of the data. Cohen's kappa values [28] were calculated to evaluate interrater reliability: for example, the kappa values for happiness-self and happiness-other were 0.750 and 0.671 , respectively. The kappa values of 18 categories ranged between $0.542-1.000(\mathrm{M}=0.768, \mathrm{SD}=0.144)$. Four categories 
(politics-self, hedonistic-other, health-other, aesthetic-other) occurred rarely in both the co-coded and the whole data. Thus, even one discrepancy could lower the kappa-value to an unacceptable level $(-0.012-0.000)$. Disagreements were discussed and adjustments to the code book were made accordingly. The first author then conducted the analysis of the remaining data sets.

\section{Results}

\subsection{Contents of Purposes Among Finnish Student Teachers and Practising Teachers}

According to the means of the seven dimensions of Roberts and Robins' [21] scale the most important content categories of the student teachers were relationship-related, hedonistic, social and economic (Table 1). Religion, aesthetics, and political influence were rated the lowest. The majority of the variables correlated statistically significantly with each other (Table 1).

Table 1. The contents of the Finnish student teachers' aspirations as measured on Roberts and Robins' (2000) scale.

\begin{tabular}{|c|c|c|c|c|c|c|c|c|}
\hline \multirow[b]{2}{*}{$\begin{array}{l}\text { Categories of } \\
\text { Roberts and Robins's scale }\end{array}$} & \multicolumn{3}{|c|}{ Student Teachers $N=912$} & \multicolumn{4}{|c|}{ Non-Parametrical Correlations } & \multirow[b]{2}{*}{6} \\
\hline & $N$ & $\mathrm{M}(\mathrm{SD})$ & 1 & 2 & 3 & 4 & 5 & \\
\hline Relationships & 907 & $4.29(0.78)$ & - & & & & & \\
\hline Hedonism & 909 & $3.73(0.80)$ & $0.133 * *$ & - & & & & \\
\hline Social & 911 & $3.23(0.89)$ & $0.140^{* *}$ & $0.231^{* *}$ & - & & & \\
\hline Economic & 911 & $2.72(0.75)$ & $0.277^{* *}$ & $0.359 * *$ & $0.065^{*}$ & - & & \\
\hline Religion & 910 & $2.02(1.25)$ & $0.138^{* *}$ & 0.012 & $0.289 * *$ & 0.022 & - & \\
\hline Aesthetics & 910 & $1.78(0.77)$ & -0.051 & $0.192 * *$ & $0.238^{* *}$ & $0.211^{* *}$ & $0.190 * *$ & - \\
\hline Political influence & 910 & $1.61(0.73)$ & 0.062 & $0.258^{* *}$ & $0.233^{* *}$ & $0.453^{* *}$ & $0.105^{* *}$ & $0.259^{* *}$ \\
\hline
\end{tabular}

Table 2 reports the content analysis of the written responses and shows how Robert and Robins's categories did not capture some of the most frequently mentioned contents, including happiness, work, and self-actualisation as well as less frequently declared health. However, the others were in practically the same order as reported above.

Table 2. The contents of the Finnish students' and practising teachers' aspirations according to the written statements.

\begin{tabular}{|c|c|c|c|c|c|c|c|c|c|c|c|c|}
\hline \multirow[b]{2}{*}{$\begin{array}{l}\text { Categories in the } \\
\text { written statements }\end{array}$} & \multicolumn{6}{|c|}{ Student Teachers $N=912$} & \multicolumn{6}{|c|}{ Practising Teachers $N=77$} \\
\hline & $N$ & $\%$ & $\begin{array}{c}\text { Self } \\
n\end{array}$ & $\%$ & $\begin{array}{c}\text { Other } \\
n\end{array}$ & $\%$ & $N$ & $\%$ & $\begin{array}{c}\text { Self } \\
n\end{array}$ & $\%$ & $\begin{array}{c}\text { Other } \\
n\end{array}$ & $\%$ \\
\hline Happiness & 568 & 62 & 520 & 57 & 182 & 20 & 55 & 71 & 52 & 68 & 20 & 26 \\
\hline Relationships & 402 & 44 & 318 & 35 & 133 & 15 & 10 & 13 & 5 & 6 & 5 & 6 \\
\hline Work & 311 & 34 & 274 & 30 & 69 & 8 & 11 & 14 & 8 & 10 & 3 & 4 \\
\hline Self-actualization & 245 & 27 & 240 & 26 & 23 & 3 & 21 & 27 & 21 & 27 & & \\
\hline Hedonism & 158 & 17 & 158 & 17 & 3 & 0 & 11 & 14 & 11 & 14 & & \\
\hline Social & 112 & 12 & 26 & 3 & 96 & 11 & 3 & 4 & & & 3 & 4 \\
\hline Political influence & 105 & 12 & 19 & 2 & 94 & 10 & 5 & 6 & 1 & 1 & 4 & 5 \\
\hline Economic & 70 & 8 & 69 & 8 & 5 & 1 & 1 & 1 & 1 & 1 & & \\
\hline Religion & 51 & 6 & 37 & 4 & 24 & 3 & & & & & & \\
\hline Health & 44 & 5 & 43 & 5 & 5 & 1 & 4 & 5 & 4 & 5 & & \\
\hline Aesthetics & 29 & 3 & 24 & 3 & 8 & 1 & 1 & 1 & 1 & 1 & & \\
\hline
\end{tabular}

The numbers related to the written responses refer to the number of participants. $N$ means how many participants mentioned this particular content, and $n$ refers to how many participants expressed the content benefitting oneself or others. The content categories in italics were created inductively by Manninen, Kuusisto, and Tirri [26] and Tirri and Kuusisto [27]. 
The main content category for over half of the student $(n=568,62 \%)$ and practising ( $n=55,71 \%$ ) teachers was happiness (Table 2). The participants referred explicitly to happiness, becoming happy or having a good life, a balanced life, being a good person and being loved. Happiness was generally self-oriented, but it was also wished for others including people who were close, or generally everyone. Participants did not wish to pursue happiness at the expense of others, aspiring instead to achieve it "while respecting all people and nature" (Student teacher 1208) or "while causing as little damage as possible to the rest of the world" (Student teacher 1265). Some of them expressed happiness as their ultimate goal, which they were realising via other and more concrete goals such as having a family, doing meaningful work, self-development, living in accordance with their values, helping others, making the world a better place, having enough income, serving God, maintaining health or doing art. In some cases, happiness was a prerequisite for a higher-level aspiration such as working as a teacher or being a parent, for example one participant mentioned: " . . When I am happy I am a better mom." (Student teacher 2271).

Almost half ( $n=402,44 \%$ ) of the student teachers placed relationships at the core of their aspirations. They wanted to have their own family, spouse, and children, to become a good mother or father, and to have close friendships. An older student pointed out that because she no longer had a family, her friends had become even more important in her life. In addition to mentioning relationships bringing meaning to themselves, the participants expressed a BTS-orientation in how they would take care of their family and raise their children "to become good people who can take others into account" (Student teacher 1331), considering it important to "create as good a basis for life as possible for their children" (Student teacher 1172). Parenthood had even changed their life purpose, as one student wrote: "Becoming a mother deepened my purpose. My task as a mother is to help my child to find a good life." (Student teacher 2271).

Twenty-seven per cent $\left(n_{\text {student teachers }}=245, n_{\text {practising teachers }}=21\right)$ of the teachers rated self-actualisation among the most important content category. They wanted to learn new things and to focus on self-development, in line with the notion of lifelong learning and the ethical code of Finnish teachers $[12,13]$. Even though self-actualisation naturally relates to the self, the teachers wished to share their learning and to give the same opportunities to others: "I want be an example, showing how people can live their lives as they wish, in freedom, joy and love" (Student teacher 1053); "My purpose is to be my authentic self and also to help other people to be what they truly are." (Student teacher 1378).

Even hedonistic life goals were considered potential purposes: not only did the teachers want to enjoy life themselves, they also wished to help others to do so, to have new experiences, and to travel.

Among the Finnish teachers, social goals (included helping) $\left(n_{\text {student teachers }}=112\right.$, $\left.12 \%, n_{\text {practising teachers }}=3,4 \%\right)$ and having political influence $\left(n_{\text {student teachers }}=105,12 \%\right.$, $n_{\text {practising teachers }}=5,6 \%$ ) were more often oriented beyond-the-self than towards self (Table 2). The student teachers in particular wanted to help the weak and to engage in voluntary work for children, youth, animals and nature. Some of them felt passionately that they were put on earth to help children in need: "My existence is about helping abused children" (Student teacher 4376). Political influence was related to helping and influencing on the societal and global levels. The participants were determined to "make the world a better place" (Student teacher 4162) and "to live so that forthcoming generations could live in a safe (economically stable, free of conflict) and diverse (plentiful natural resources, stable climate, clean nature) (world)" (Student teacher 2117). Helping others and having political influence were also seen as benefitting oneself: "(my purpose is) to help others and through that to help myself" (Student teacher 1122).

Contents related to economic matters, religion, health, and aesthetics were rated the low both on Roberts and Robins's scale and in the written responses (Tables 1 and 2). Orientation to financial wealth among the teachers was relatively modest. They aimed to be economically independent and to be able to support themselves and their future family, and to support those in financial need: "I also want to be independent financially. 
To help those closest to me, and other people, also financially" (Student teacher 1079). Even though religion and spirituality were on a general level mentioned seldom, these matters were highly important for some individuals, even providing a framework and a basis for their whole life $[27,29]$. This was also evident in Roberts and Robins's scale, in the largest standard deviation within religion category $(S D=1.24)$.

A few teachers $\left(n_{\text {student teachers }}=44, n_{\text {practising teachers }}=4\right)$ mentioned having a long and healthy life or being creative in music and writing $\left(n_{\text {student teachers }}=29, n_{\text {practising teachers }}=1\right)$, such as: "To become a musician" (Student teacher 1371); "To be a published author" (Student teacher 4598).

Sixty $(7 \%)$ of the student teachers and one practising teacher were still unclear about their purpose, or they were searching for one. Some students ( $n=37 ; 4 \%)$ claimed not to have a purpose and did not see the relevance of this type of reflection: "life does not have a purpose" (Student teacher 1050); "you cannot define one clear purpose. It is vain and not relevant. You just need to live" (Student teacher 1166); "I do not commit nor want to commit (to any purposes) because I really do not want anything so desperately. Goals and aims I do have, like becoming a teacher" (Student teacher 1076).

Table 3 shows the associations between the quantitative and qualitative data and the background variables. Among the student teachers, six of the content categories were statistically significantly more important for females than for males. However, of these, the relationships category was the only one in which gender difference was detected in both the quantitative and the qualitative data. There were a few age-related similarities in the quantitative and qualitative datasets: among both student teachers and practising teachers, for example, members of the youngest group (18-28-year-olds) showed the most interest in hedonistic aspirations. Moreover, work was important among the youngest group of students as well as the oldest group of practising teachers. With regard to educational background, students who were aiming to become class and Kindergarten teachers differed from those aspiring to be subject teachers: the class teachers specifically highlighted happiness, hedonism, and helping others (social), whereas the Kindergarten teachers emphasised relationships, helping others, work, political influence, as well as hedonistic and economic interests.

Table 3. The contents of the Finnish students' and the practising teachers' aspirations in relation to gender, age, and education.

\begin{tabular}{|c|c|c|c|c|c|c|c|c|c|c|c|c|}
\hline & \multicolumn{9}{|c|}{ Student Teachers $N=912$} & \multicolumn{3}{|c|}{ Practising Teachers $N=77$} \\
\hline & \multicolumn{3}{|c|}{ Gender } & \multicolumn{3}{|c|}{ Age } & \multicolumn{3}{|c|}{ Education } & \multirow{2}{*}{$\begin{array}{l}\text { Gender } \\
\chi^{2}(1)\end{array}$} & \multirow{2}{*}{$\begin{array}{c}A g e \\
\chi^{2}(2)\end{array}$} & \multirow{2}{*}{$\begin{array}{c}\text { Education } \\
\chi^{2}(2)\end{array}$} \\
\hline & $r_{s}$ & $\chi^{2}(1)$ & & $r_{\mathrm{s}}$ & $x^{2}(2)$ & & $r_{s}$ & $\chi^{2}(2)$ & & & & \\
\hline Happiness & & $33.181 * * *$ & Fem & & 0.778 & & & $14.133^{* *}$ & $\mathrm{C}$ & 1.192 & 0.708 & 0.933 \\
\hline Relationships & $0.217^{* *}$ & $9.665^{* *}$ & Fem & -0.058 & 1.586 & & $-0.246^{* *}$ & $10.378^{* *}$ & $\mathrm{~K}$ & 0.811 & 0.082 & 1.079 \\
\hline Work & & $5.952 *$ & Fem & & $7.553 *$ & $18-28$ & & $7.805^{*}$ & $\mathrm{~K}$ & 0.883 & $9.126 * 40-$ & 1.793 \\
\hline Self-actualization & & $6.542 *$ & Fem & & 1.246 & & & 1.814 & & 0.497 & 0.743 & 0.041 \\
\hline Hedonism & $0.089^{* *}$ & 0.004 & Fem & $-0.239 * *$ & $8.093 *$ & $18-28$ & $-0.179 * *$ & 2.983 & $\mathrm{C}, \mathrm{K}$ & 0.014 & $7.467 * 18-28$ & 0.756 \\
\hline Social & $0.149 * *$ & 0.016 & Fem & 0.030 & 0.570 & & $-0.170 * *$ & 0.086 & $\mathrm{C}, \mathrm{K}$ & 0.755 & 5.103 & 2.743 \\
\hline Political influence & -0.053 & 3.063 & & -0.011 & 2.611 & & $-0.111 * *$ & 2.696 & $\mathrm{~K}$ & 0.001 & 3.384 & 1.798 \\
\hline Economic & $0.090 * *$ & 0.525 & Fem & $-0.146^{* *}$ & $8.517^{*}$ & $18-28$ & $-0.119 * *$ & $9.334^{* *}$ & $\mathrm{~K}$ & 0.245 & 0.720 & 1.876 \\
\hline Religion & -0.002 & 1.396 & & 0.033 & 1.318 & & -0.033 & 1.415 & & & & \\
\hline Health & & 0.392 & & & 1.626 & & & 3.526 & & 0.082 & 3.000 & 0.239 \\
\hline Aesthetics & -0.042 & $6.428 *$ & Male & 0.026 & 0.905 & & 0.000 & 1.387 & & 0.245 & 0.720 & 4.559 \\
\hline
\end{tabular}

$r_{s}=$ Spearman's non-parametric correlation; $\chi^{2}(\mathrm{~d})=$ Pearson's chi-square. ${ }^{* * *} p<0.001,{ }^{* *} p<0.01,{ }^{*} p<0.05$. Compared groups: Gender: Fem = Female, Male; Age: 18-28, 29-39, 40-; Education: K = Kindergarten teacher (only student teachers), $C=$ Class teacher, $S=$ Subject teacher, $\mathrm{Sp}=$ Special education teacher (only practising teachers).

When we looked at self- and BTS-orientation on the individual teacher level (Table 4) we noticed that about half of the respondents had expressed only a self-orientation in their answers ( $n_{\text {student teacher }}=420 ; 46 \% ; n_{\text {practising teacher }}=42 ; 55 \%$ ). Around 40 per cent had manifested BTS-orientation $\left(n_{\text {student teacher }}=392 ; 43 \%\right.$; $n_{\text {practising teacher }}=28 ; 36 \%$ ), including those who only focused on others or who combined a self- and BTS-orientations. Finally, we were able to identify a family orientation $\left(n_{\text {student teacher }}=54 ; 6 \% ; n_{\text {practising teacher }}=2 ; 3 \%\right.$ ), mention of their own family being the only indicator of taking into account the perspectives of others. No statistically significant differences were found between orientation and gender or education. However, there was a statistically significantly association with age among 
the student teachers: self-orientation was supported by over half of the 18-28-year-olds ( $n=314,53 \%)$ whereas the numbers were lower in the other groups (29-39-year-olds $n=82$, $36 \%$; over 40 -year-olds $n=25,29 \%$ ).

Table 4. Purpose orientations.

\begin{tabular}{ccccc}
\hline Orientations & $\begin{array}{c}\text { Student Teachers } \\
\mathbf{N = 9 1 2}\end{array}$ & $\mathbf{\%}$ & $\begin{array}{c}\text { Practising Teachers } \\
\mathbf{N = 7 7}\end{array}$ & $\mathbf{\%}$ \\
\hline Self & 421 & 46 & 42 & 55 \\
Beyond-the-self (Other or self + other) & 391 & 43 & 28 & 36 \\
Family as the only other & 54 & 6 & 2 & 3 \\
No purpose & 37 & 4 & 1 & 0 \\
No answer & 9 & 1 & 4 & 5 \\
\hline
\end{tabular}

\subsection{Finnish Teachers Incorporating Professional Aspects into Their Life Purposes}

As shown in Table 2 , work $\left(\mathrm{n}_{\text {student teachers }}=311 ; 34 \% ; \mathrm{n}_{\text {practising teachers }}=11 ; 14 \%\right)$ was among the major contents of purpose. The student teachers wanted to find work that was meaningful and purposeful. Ten per cent $(n=100)$ of student teachers explicitly mentioned teaching as their dream, calling or purpose: "My purpose in life is to teach what I can and whom I can, to help others to grow and to understand life" (Student teacher 1064). "(For me the most important purpose is to have a happy relationship and family life) and secondly to defend children's rights to a good life and participate in their upbringing as a Kindergarten teacher" (Student teacher 1330). The majority of participants used words such as work, job and occupation, which in the context of teacher education and school could be interpreted as referring to the teaching profession. Nevertheless, some student teachers seemed to refer to other occupations, and some wrote about their uncertainty with regard to their professional path: "Professionally I do not have a clear purpose, even though I am studying to become a teacher" (Student teacher 4129).

When the practising teachers were asked directly how teaching related to their purpose, the majority ( $n=60 ; 78 \%$; Table 5 ) replied that their aspirations were actualised in teaching, which brought happiness, meaning, learning experiences, and opportunities for self-actualisation: teaching was seen as a mediator, indicating self-orientation. The respondents also pointed out that teaching offered opportunities to help and guide children and young people, thereby demonstrating a BTS-orientation. A few $(n=5 ; 6.5 \%)$ did not see a link between their purpose and teaching, and some $(n=12 ; 15.5 \%)$ gave unclear answers.

Table 5. Teachers' perceptions on how teaching manifests in their life purposes.

\begin{tabular}{cc}
\hline Categories & Practising Teachers \\
& $\boldsymbol{N}=\mathbf{7 7}(\%)$ \\
\hline Teaching as a mediator & $60(78)$ \\
Beyond-the-self-orientation (Other or self and other) & $34(44)$ \\
Self-orientation & $26(33)$ \\
No role & $5(6.5)$ \\
Unclear answer & $12(15.5)$ \\
\hline
\end{tabular}

\section{Discussion}

In this article we have discussed the challenge of educating purposeful teachers in Finland. Given the new demands of the 21st century and the decreasing number of teacher candidates in Finland, we perceive a need for more emphasis on meaningful teacher education that combines the personal and professional interests of future teachers. We analysed data from student teachers $(N=912)$ and practising teachers $(N=77)$ to find out what purposes Finnish teachers considered important in their lives and how they incorporated professional aspects into their life purposes.

We assessed the interests of Finnish student teachers using Roberts and Robins's [21] Life Goal Questionnaire, and we found that relationships and hedonistic goals were the 
most valued, and economic matters, religion, aesthetics and political influence were the least important. These results align with those reported in the original study conducted among American undergraduate students [21] and Finnish university students of social services [26]. However, qualitative content analysis of the student and the practising teachers' own descriptions revealed that Roberts and Robins's categories did not capture all of the major content categories, namely happiness, work, and self-actualisation. All in all, happiness and relationships were the most frequently mentioned contents, as they were among Finnish students of social services [26]. These contents also reflected the goals and values identified in national samples of Finnish youth and young adults [30].

In addition to analysing the content categories, we also considered the beneficiaries of the teachers' aspirations: whether their aspirations demonstrated a self-orientation, or whether they were interested in contributing beyond-the-self. The results showed, first, that all contents were associated with both orientations, illustrating empirically that even hedonistic goals may benefit others, and that social purposes (interest in helping and volunteering) may include self-focused motivations. Second, they imply that using only content categories as indicators of self- or beyond-the-self -orientation might not be enough [6,31], thereby highlighting the need to develop qualitative approaches that illustrate how individuals construct meanings and connect them to their aspirations. Nevertheless, contents related to social issues, political influence and religion were generally strongly allied with beyond-the-self-orientation, whereas all other contents related mainly to self-orientation.

We also found that most of the descriptions of the students and the practising teachers were self-oriented, indicating that within Damon et al.'s [4] and Tirri's [1] framework these participants did not exhibit the purpose or the profile of a purposeful teacher. Further, for some the other-focus referred only to their own family. Self-orientation was especially prevalent among the youngest student teachers, aged 18-28. There was a visible association between personal life purpose and work in 34 per cent $(n=311)$ of the student teachers and 14 per cent $(n=11)$ of the practising teachers' statements, but only ten per cent in total explicitly mentioned teaching as their dream, calling, or purpose. Moreover, work was referred to mainly as self-beneficial and only a minority of the participants mentioned serving other people, society, or other noble causes. The majority of the teachers did not refer to teaching in their answers at all, nor did they consider it important to contribute to the well-being of other people or society. However, when the practising teachers were asked directly how their purpose in life was associated with their work, over half of them identified a link: teaching was seen as a mediator in realising their personal purposes or aspirations. Through teaching they could make their own life meaningful, actualise themselves, and contribute to the lives of others.

From the perspective of the purposeful teacher, the results of the present study reveal challenges for teacher education. Finnish teachers seem to be rather self-oriented, interested in their own meaning-making, and in what benefits themselves. The rather strong prevalence of self-orientation among Finnish student teachers and practising teachers could be one possible explanation for teacher burnout and attrition, since according to previous empirical studies, self-orientation does not help individuals to face and cope with challenges as well as focus on benefitting others [32]. Teacher education in the twentyfirst century should therefore nurture more beyond-the-self -orientation in teachers and explicitly help them build bridges between personal purposes and the teaching profession. This kind of approach could support professional learning among teachers, especially from a motivational perspective [3]. The educational system in Finland is well known for its whole-person approach that takes into consideration not only the cognitive but also the affective, behavioural, moral, social, physical, and spiritual domains [33]. Given the results of this study, it seems that Finnish teacher education has not been able to actualise this approach in its programs.

Thus, our results indicate the need for a whole-person approach to teacher education that helps prospective teachers to reflect on and develop their purposes, from selforientation towards beyond-the-self orientation. Concretely, Finnish universities should 
establish opportunities in teacher education to reflect on teacher ethics and purposeful teaching [18]. Some methods have already been developed. Tirri and Kuusisto [34], for example, have presented a case-study approach in which teachers learn to analyse teachingstudying-learning experiences and to identify elements that make teaching purposeful and learning personally meaningful. Nevertheless, findings from the present study indicate that more systematic procedures and policies are needed to build more sustainable approaches.

The study has several limitations. First, even though we had extensive data from student teachers, the practising teachers represented only one Finnish basic-education school, and the sample $(N=77)$ is too small to draw generalisable conclusions. Second, both datasets were cross-sectional in nature, which means that the study gives a state-of-the art overview and as such contributes to both fields of study, namely teacher education and purpose, but it does not identify the developmental aspects of life purposes among teachers. Longitudinal research and intervention are needed to find out how purpose develops during pre- and in-service teacher education, and how whole-person approaches support the development of personal and professional purposes and their meaningful integration. Third, considering the relatively short nature of the written statements, a series of in-depth analyses of interviews with focus groups and privileged witnesses, and of narrative writings could provide a more nuanced and deeper understanding of teachers' life purposes and their links to teaching.

To conclude, the findings of the present study have implications concerning research and practice in teaching and teacher education. Teacher education needs ethical frameworks and moral goals that promote the education of good individuals and citizens for the twenty-first century who find meaning and purpose in serving others. In this paper, we have found the purposeful teacher as a challenge but also a moral goal for teachers of the twenty-first century. With these contributions we hope to advance purposeful education and advocate the development of purposeful teaching that could be applied in teacher education around the world.

Author Contributions: Conceptualization, methodology, validation, E.K. and K.T.; writing-Original draft preparation, E.K.; writing—Review and editing, E.K. and K.T.; project administration, E.K.; funding acquisition, K.T. All authors have read and agreed to the published version of the manuscript.

Funding: This work was supported in part by a subcontract (grant number 2013-053) from Clark University to the University of Helsinki (Kirsi Tirri, PI), based on a grant to Clark University (Seana Moran, PI) from The John Templeton Foundation, USA. The opinions expressed in this article are of the authors and do not necessarily reflect the opinions of The John Templeton Foundation.

Informed Consent Statement: Informed consent was obtained from all subjects involved in the tudy.

Conflicts of Interest: The authors declare no conflict of interest.

\section{References}

1. Tirri, K. The purposeful teacher. In Teacher Education in the 21st Century; Monyai, R., Ed.; IntechOpen: London, UK, 2019. [CrossRef]

2. Kansanen, P.; Tirri, K.; Meri, M.; Klokfors, L.; Husu, J.; Jyrhämä, R. Teachers' Pedagogical Thinking, Theoretical Landscapes, Practical Challenges; Peter Lang: New York, NY, USA, 2000.

3. Boeskens, L.; Nusche, D.; Yurita, M. Policies to Support Teachers' Continuing Professional Learning: A Conceptual Framework and Mapping of OECD Data; OECD Education Working Paper No. 235; OECD: Paris, France, 2020. Available online: http:/ /www.oecd. org/education/policies-to-support-teachers-continuing-professional-learning-247b7c4d-en.htm (accessed on 5 January 2021).

4. Damon, W.; Menon, J.; Bronk, K.C. The development of purpose during adolescence. Appl. Dev. Sci. 2003, 7, 119-128. [CrossRef]

5. Frankl, V.E. Man's Search for Meaning; Pocket Books: New York, NY, USA, 1988.

6. Moran, S. Purpose: Giftedness in intrapersonal intelligence. High Abil. Stud. 2009, 20, 143-159. [CrossRef]

7. Damon, W. Noble Purpose; Templeton Foundation Press: London, UK, 2003.

8. Day, C. Teachers' moral purposes: A necessary but insufficient condition for successful teaching and learning. In Encyclopedia of Teacher Education; Peters, M., Ed.; Springer: Singapore, 2019. [CrossRef]

9. Tirri, K.; Husu, J.; Kansanen, P. The epistemological stance between the knower and the known. Teach. Teach. Educ. 1999, 15, 911-922. [CrossRef]

10. Han, H. Purpose as a moral virtue for flourishing. J. Moral Educ. 2015, 44, 291-309. [CrossRef] 
11. Harrison, T. Virtue ethics in teacher education. In Encyclopedia of Teacher Education; Peters, M., Ed.; Springer: Singapore, 2019. [CrossRef]

12. Trade Union of Education in Finland. Ethical Principles of Teaching. 2020. Available online: https://www.oaj.fi/en/education/ ethical-principles-of-teaching/teachers-values-and-ethical-principles/ (accessed on 5 January 2021).

13. Trade Union of Education in Finland. Comenius Oath. 2017. Available online: https://www.oaj.fi/en/education/ethicalprinciples-of-teaching/comenius-oath-for-teachers/ (accessed on 5 January 2021).

14. Oser, F. Professional morality: A discourse approach (the case of the teaching profession). In Handbook of Moral Behavior and Development; Kurtines, W., Gewirtz, J., Eds.; Lawrence Erlbaum Associates: Hillsdale, NJ, USA, 1991; Volume 2, pp. 191-228.

15. Tirri, K.; Husu, J. Care and Responsibility in 'The Best Interest of the Child': Relational voices of ethical dilemmas in teaching. Teach. Teach. 2002, 8, 65-80. [CrossRef]

16. Clydesdale, T. The Purposeful Graduate; The University of Chicago Press: Chicago, IL, USA, 2015.

17. Deresiewicz, W. Excellent Sheep: The Miseducation of the American Elite and the Way to a Meaningful Life; Free Press: New York, NY, USA, 2014.

18. Colby, A. Purpose as a unifying goal for higher education. J. Coll. Character 2020, 21, 21-29. [CrossRef]

19. Damon, W. Path to Purpose. How Young People Find Their Calling in Life; Free Press: New York, NY, USA, 2008.

20. Moran, S. How Service-Learning Influences Youth Purpose around the World, Student Semester Start Survey; Qualtrics Version; Kuusisto, E.; Tirri, K., Translators; Clark University: Worcester, MA, USA, 2014. (In Finnish)

21. Roberts, B.W.; Robins, R.W. Broad dispositions, broad aspirations: The intersection of personality traits and major life purposes. Personal. Soc. Psychol. Bull. 2000, 26, 1284-1296. [CrossRef]

22. Bundick, M.; Andrews, M.; Jones, A.; Mariano, J.M.; Bronk, K.C.; Damon, W. Revised Youth Purpose Survey; Stanford Center on Adolescence: Stanford, CA, USA, 2006.

23. Magen, Z. Exploring Adolescent Happiness: Commitment, Purpose, and Fulfilment; Sage: Thousand Oaks, CA, USA, 1998.

24. Natow, R.S. The use of triangulation in qualitative studies employing elite interviews. Qual. Res. 2020, 20, 160-173. [CrossRef]

25. Elo, S.; Kyngäs, H. The qualitative content analysis process. J. Adv. Nurs. 2008, 62, 107-115. [CrossRef] [PubMed]

26. Manninen, N.; Kuusisto, E.; Tirri, K. Life goals of Finnish social services students. J. Moral Educ. 2018, 47, 1-11. [CrossRef]

27. Tirri, K.; Kuusisto, E. What is purpose in life among Finnish theology students? In Understanding Religion: Empirical Perspectives in Practical Theology: Essays in Honour of Hans-Georg Ziebertz; Riegel, U., Heil, S., Kalbheim, B., Unser, A., Eds.; Waxmann: Münster, Germany, 2019; pp. 97-108.

28. McHugh, M.L. Interrater reliability: The kappa statistic. Biochem. Med. 2012, 22, 276-282. [CrossRef]

29. Tirri, K.; Quinn, B. Exploring the role of religion and spirituality in the development of purpose: Case studies of purposeful youth. Br. J. Relig. Educ. 2010, 32, 201-214. [CrossRef]

30. Salmela-Aro, K.; Aunola, K.; Nurmi, J.-E. Personal goals during emerging adulthood: A 10-year follow up. J. Adolesc. Res. 2007, 22, 690-715. [CrossRef]

31. Bundick, M.J.; Tirri, K. Student perceptions of teacher support and competencies for fostering youth purpose and positive youth development: Perspectives from two countries. Appl. Dev. Sci. 2014, 18, 148-162. [CrossRef]

32. Salmela-Aro, K.; Nurmi, J.-E. Goal contents, well-being and life context during transition to university-A longitudinal study. Int. J. Behav. Dev. 1997, 20, 471-491. [CrossRef]

33. Tirri, K.; Kuusisto, E. How Finland Serves Gifted and Talented Pupils. J. Educ. Gift. 2013, 36, 84-96. [CrossRef]

34. Tirri, K.; Kuusisto, E. How can purpose be taught? J. Relig. Educ. 2016, 64, 101-112. [CrossRef] 